\title{
Quality certification model for care management in Chilean hospitals
}

\author{
Modelo de certificación de calidad para la gestión del cuidado en hospitales chilenos \\ Modelo da certificação da qualidade da gestão do cuidado em hospitais chilenos \\ Maria Cristina Torres Andrade*; Javier Alarcón**; Angela Berthet***; Viviana Cantero****; \\ Daniela Llanquipichún ${ }^{* * * * *}$; Daniela Sáez ${ }^{* * * * * *}$; Ignacio Yáńez $z^{* * * * * * *}$
}

\begin{abstract}
Background: In Chile, care management is a Nursing responsibility, being mandatory in Chilean complex hospital settings. However, there are no instruments to certify its quality and allow for its integration within the strategic organization of the Sub-Directorates for Care Management.

Objectives: To identify, on a consensual basis, the concept and dimensions associated with care management, as well as the processes, outcomes and indicators of each dimension.

Methodology: The Delphi methodology was used to identify the concepts, dimensions, processes and outcomes in consultation with experts. The research team analyzed and reached a consensus on the answers. These answers were consecutively validated using focus groups with health professionals from public and private hospitals in order to develop the model.

Results: The following dimensions were obtained: i) Relevance and Cost-Effectiveness of Nursing Actions; ii) Power and Relationship with Others; and iii) Nursing Research and Training. Each dimension was composed of the respective clinical processes, outcomes and indicators.

Conclusion: The matrix is a flexible and appropriate model to assess the needs of the institutions, providing visibility to the clinical processes associated with care management and the certification of its quality.
\end{abstract}

Keywords: nursing; hospital management; clinical management

\section{Resumen}

Marco contextual: En Chile, la Gestión del cuidado es responsabilidad de la enfermería y obligatoria en hospitales complejos. No hay instrumentos que certifiquen su calidad para que sea parte de la conducción estratégica de subdirecciones de Gestión del Cuidado. Objetivos: Determinar de manera consensuada el concepto y las dimensiones asociadas a la gestión del cuidado; los procesos, resultados e indicadores de cada dimensión.

Metodología: Se utilizó metodología Delphi para obtener conceptos, dimensiones, procesos y resultados desde los expertos. El equipo investigador analizó y consensuó repetidamente las respuestas. Estas fueron validadas sucesivamente en grupos focales de profesionales clínicos de hospitales públicos y privados, para obtener el modelo. Resultados: Se obtuvieron las dimensiones: i) Pertinencia y Costoefectividad de las Acciones de Enfermería, ii) Poder y Relación con Otros e iii), Investigación y Formación en Enfermería, con sus procesos, resultados e indicadores.

Conclusión: La matriz se constituye en un modelo flexible y apropiado a las necesidades de los establecimientos, que visibiliza procesos clínicos involucrados en la gestión del cuidado, pudiendo certificar su calidad.

Palabras clave: enfermeira; administración hospitalária; gestión clínica

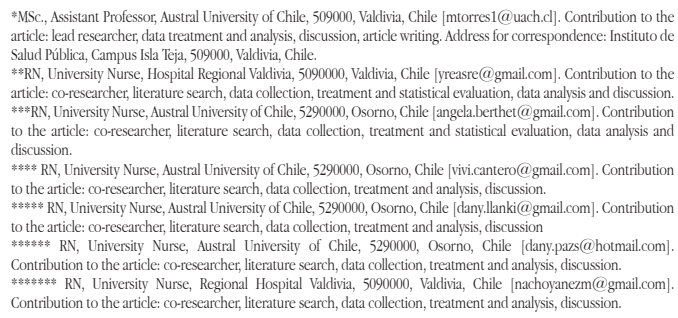

\section{Resumo}

Enquadramento: No Chile, a Gestão dos Cuidados é obrigatória para hospitais complexos e também, responsabilidade legal da enfermagem. Não há instrumentos que atestem a sua qualidade para que seja parte da condução estratégica das Subdireções de Gestão do Cuidado.

Objetivos: Determinar participativamente o conceito e as dimensões associadas à Gestão dos Cuidados, os processos, resultados e indicadores de cada dimensão.

Metodologia: A metodologia Delphi foi utilizada para obter conceitos, dimensões, processos e resultados dos expertos. A equipa investigadora analisou e acordou as respostas. Para obter o modelo, estas foram validadas sucessivamente em grupos focais de profissionais clínicos de hospitais públicos e particulares.

Resultados: Foram obtidas as dimensões: i) Pertinência e Custo Efetividade ii) poder e relação com os outros e iii) Pesquisa e Formação em Enfermagem, com seus processos, resultados e indicadores.

Conclusão: A matriz consenso constitui-se num modelo flexível e apropriado às necessidades dos estabelecimentos, visibilizando os processos clínicos envolvidos na gestão dos cuidados, podendo certificar-se sua qualidade.

Palavras-chave: enfermagem; administração hospitalar; gestão clínica

Received for publication: 23.03 .15

Accepted for publication: 14.04 .16 


\section{Introduction}

In Chile, Care Management is defined as "what concerns the promotion, maintenance and restoration of health, the prevention of illness or injury and the implementation of actions arising from the medical diagnosis and treatment, and the duty to ensure the best management of the patient support resources" (Gobierno de Chile, 2004). Despite the progress in the political and legal domains, the operational aspects of care management are not fully developed and nursing professionals find it hard to make a conceptual and practical distinction between nursing care management, general management, clinical management and care management. The latter aspect is not identified as such in hospital accreditation; therefore, is essential to identify a model that includes various aspects of inpatient Care Management quality, where the Care Management is a legal responsibility for nurses.

\section{Background}

As a new aspect in the Nursing discipline that focuses on the satisfaction of the needs of the individual, family and his/her place in the community, as well as the implementation of actions arising from the medical diagnosis and treatment (Gobierno de Chile, 1968), Care management is achieved through nurse's judgment. In inpatient care, different domains are addressed - administration, working unit, and health team - and different levels - strategic, tactical, and operational (Ayala, 2014).

According to the Ministry of Health of Chile, Care Management is the exercise of personal, professional and instrumental competences to organize, coordinate and articulate the care at its different levels, thereby ensuring the continuity and effectiveness of care (Subsecretaria de Redes Asistenciales, 2007). Although it is an adequate general definition for the Nursing intervention, it does not clarify its specific configurations or the areas to which it applies, making it difficult to accurately assess professional compliance. Therefore, Care Management is not based on concrete quality standards which allow ensuring the quality of the performed actions. Some progresses have been made in the standardization of nursing actions, which are important for care management, such as the patient classification according to care needs, but it is still necessary to articulate the standards in a model that allows a comprehensive perception of care management aimed at patients and their families. In addition, future Sub-Directorates for Care Management must maintain self-assessment systems to collect scientific evidence on the scope and magnitude of the actions specific to Nursing. The possibility of assessing the quality of care management and, therefore, of Nursing, enhances the autonomy and greater visibility within the healthcare institution in the extent that research is the only way of moving toward the autonomy and the construction of its own body of knowledge (Federico-Ferreira \& Ribeiro da Silva, 2012).

\section{Research question}

Based on the research assumption that the quality of the Care Management can be certified within a multidimensional logic, we formulated the following research question: What are the dimensions, processes and outcomes that should be considered in certifying the quality of Care Management in complex hospital settings?

\section{Methodology}

We conducted a mixed-method study using the Delphi Method (Bravo \& Arrieta, 2005; Astigarraga, n.d.; Yáñez \& Cuadra, 2008), which involves repeated consults with a group of experts until reaching consensus, the DEFUN methodology (Torres, 2008), in which professional functions (FUN) are defined (DE) to obtain dimensions, processes, and outcomes in indicators, and focus groups. The convergence of these three methods contributed to designing the quality certification instrument. The experts' opinions were compared with the opinions of the focus groups composed of clinical nurses, who should use the model. In an initial approach to the corpus obtained through the focus groups, the content was analyzed in its inductive approach, using proximity and closeness, contrast or differentiation, and saturation or persistence of the opinions (Amezcua, 2003; Bertoldi, Fiorito, \& Alvarez, 2006; Amezcua \& Galvez, 2002). The experts were consulted separately by email. They 
did not know the opinions of other participants in the panel, only receiving the consecutive consensus. Within the DEFUN, the research team analyzed the experts' proposals, which were passed on to the members of the focus groups, who adjusted the instrument to the practice. We recorded the sessions with the focus groups and took field notes in order to highlight the setting and relevant aspects of the meetings.

A non-probability sample was used to select the panel of experts from the academic, ministerial and union fields, elected at the suggestion of key informants on the basis of their academic training, workplace, availability and accessibility. The research team invited 40 experts, 10 of whom remained as members of the team until the end of the three-year research period. The clinical teams for the focus groups were selected by the Care Management Director based on the profile indicated by the research team. The clinical teams were composed of 80 nurses from three public hospitals in the south of Chile and from a Private Clinic. These focus groups met consecutively and each new focus group worked on the contributions of the previous one, which acted as a source of dissemination of the preliminary research outcomes. The quality certification instrument was gradually designed and adjusted based on the consensus from the expert's panel, the focus groups, and the research team. The assessment of the research protocol by the Ethics Committee was not mandatory since it did not involve any patient or information relating to them. The following table summarizes the applied research design:

Table 1

Research design

\begin{tabular}{llll}
\hline STAGES & OBJECTIVE & METHOD & \\
\hline PRELIMINARY - & $\begin{array}{l}\text { Search for common and essential elements in the } \\
\text { Search, selection and } \\
\text { validation of experts }\end{array}$ & $\begin{array}{l}\text { First round of questions. } \\
\text { Open-ended questions. }\end{array}$ & E-mail \\
\cline { 2 - 4 } & Consensus and analysis of the research team & DEFUN & In person \\
\hline \multirow{2}{*}{$\begin{array}{l}\text { EXPLORATORY: } \\
\text { Analysis and consensus of } \\
\text { questionnaires } \\
\text { Consecutive feedbacks }\end{array}$} & $\begin{array}{l}\text { Search for general and common issues in each ques- } \\
\text { tion }\end{array}$ & $\begin{array}{l}\text { Second round of questions } \\
\text { Closed-ended questions }\end{array}$ & E-mail \\
\cline { 2 - 4 } & Consensus and analysis of the research team & DEFUN & In person \\
\cline { 2 - 4 } $\begin{array}{l}\text { FINAL: } \\
\text { Validation and consecu- } \\
\text { tive consensus } \\
\text { Feedback to all partici- } \\
\text { pants }\end{array}$ & Consensus and analysis of the research team & Third round of questions & E-mail \\
\cline { 2 - 4 } & menters (various). & Consens & In person \\
\cline { 2 - 4 } & Final validation with the implementers and experts & Consensus report & In person \\
\hline
\end{tabular}

Source: Methodology used in the study

We applied credibility, auditability or confirmability and transferability or applicability criteria (Castillo \& Vásquez, 2003) in the Delphi Methodology and the analysis of the focus groups. Given that participants were not patients, we used the ethics committees' standard requirements through informed consents ensuring anonymity and allowing the option of withdrawal from the research.

\section{Results}

Three complementary dimensions resulted from the consensus achieved between the experts from the academic, ministerial and union fields to characterize and conceptualize the care management. The Relevance and Cost-Effectiveness of Nursing Actions dimension relates to the demand for more effective and user-focused clinical processes by the users and the institution. This should result in a different organic structure of the Nursing care that allows for the visibility of the associated clinical processes. On the other hand, this dimension implies the need to address the technological diversity and complexity of the associated decisions. This will require frameworks of decision-making which take into account the users' needs and the technological costs and obsolescence. The Power and Relationship with Others dimension 
is considered to be the need to claim the role of Nursing within hospitals, its social position and as a way to achieve gender equity. On the other hand, it faces the need to empower the client-patientpartner so that he/she becomes more accountable for his/her own health, more capable of making informed and responsible decisions, and to create conditions for the development of a citizenship in health. In fact, these aspects contribute to define the boundaries of Care Management, the professionals included in it, and the circumstances in which they exercise Care Management. It will also serve to identify what care management is and is not. The Nursing Training and Research dimension refers to the need for incorporating innovation in the nurses' training, and evidence in their practice so as to ensure care interventions centered on the person and his/her family, along with the Nursing technical staff and multidisciplinary team. This dimension also recognizes the gaps in the scientific model to deal with complexity and uncertainty. On the other hand, the concept of profession implies the disciplinary competence to train peers while relying on the support from other disciplines, such as psychology, management, physiology.

In this sense, addressing Care Management in hospital settings means to address the Relevance and Cost-Effectiveness of Nursing Actions toward the users and the institution. It also expresses the power and responsibility derived from the relationship with other professionals, users and their families, while establishing the need to justify care and training scientifically, so that nursing advances through professionalization without neglecting the human component.

The participants implemented these dimensions through a series of procedures, techniques and processes. Afterwards, the research team organized them into similar processes, with a main identifiable outcome and plausible and verifiable indicators. The work of the research team was analyzed by two consecutive panels of experts in order to achieve a greater homogeneity in size and complexity, as well as to minimize the processes of quality certification in Care Management. These processes were then analyzed by the four focus groups, resulting in a more realistic perspective and practical knowledge on the more relevant aspects in practice, and those that can be measured or not.

It should be noted that the meeting of the four focus groups had to be repeated because it turned into assessing the nursing actions and understanding the impact of the implementation of care management on their healthcare institutions. The nurses' opinions included: "it helped me organize what I do", "I understood better the connection between things", or "it is what we do, but in a complete and organized way". Furthermore, nurses used the meeting to make immediate decisions, for example to standardize actions of emotional support toward the family in the death process, or how to deal with a lack of supplies. The conversation also focused on issues related to care management and quality assessment, such as the legal responsibilities of nursing, the delegated procedures and the conditions for delegating, as well as the fact that the institutional strategic planning does not affect the clinical services, and the possibility of the clinical services influencing the institutional strategy.

The following tables show the research outcomes. Table 2 describes the three dimensions of care management: i) Relevance and cost-effectiveness of nursing actions; (ii) Power and Relationship with Others; and iii) Nursing Research and Training. Table 3 illustrates i) the clinical processes through which each dimension is implemented, (ii) the outcomes associated with each process, and (iii) the indicators that allow the outcome to be measured. In this regard, we identified dichotomous, numeric or percentage indicators, depending on the feasibility of measurement. 
Table 2

Relevance and Cost-Effectiveness of Nursing Actions dimension

The Relevance and Cost-Effectiveness of Nursing Actions dimension is understood as:

- The demand for greater effectiveness in the clinical processes to allow them to be rationally designed as user-focused, recognizing that it requires a different organic structure of nursing.

- The need to address the diversity of the available technological resources and reduce the complexity of the associated decisions. This dimension is present in the following processes:

\begin{tabular}{|c|c|}
\hline Outcome & Indicators \\
\hline $\begin{array}{l}\text { Compliance with basic techni- } \\
\text { cal standards (BTS) and HCAI } \\
\text { prevention standards. }\end{array}$ & $\begin{array}{l}\text { - \% of patients free from health care-associated infections (HCAIs) (sentinel events or } \\
\text { of mandatory notification). \% of non-sentinel HCAIs. } \\
\text { - \% of positive cultures from staff hands and critical surfaces, with bioluminescence. } \\
\text { - \% of services with delimitation of dirty and clean areas; medication preparation facility. } \\
\text { work. }\end{array}$ \\
\hline $\begin{array}{l}\text { Safe elimination of biomedical } \\
\text { and toxic waste. }\end{array}$ & $\begin{array}{l}\text { - Institutional waste management plan, per unit and in compliance with the regulations on } \\
\text { the safe management of wastes from health-care activities (Residuos de Establecimientos } \\
\text { de Atención de Salud, REAS). } \\
\text { - \% of compliance with the regulations on the safe management of wastes from health-care } \\
\text { activities. } \\
\text { - Different containers for general, special and dangerous waste. }\end{array}$ \\
\hline $\begin{array}{l}\text { Temperature, humidity and } \\
\text { ventilation, hygiene and noise } \\
\text { compatible with safe care. }\end{array}$ & $\begin{array}{l}\text { - Thermal, acoustic and humidity isolation. } \\
\text { - } \quad \text { Odor-free, clean floors and walls. } \\
\text { - } \quad \text { Maintenance program for infrastructure, critical equipment and general equipment. } \\
\text { - \% of equipment and infrastructure with daily maintenance. }\end{array}$ \\
\hline \multicolumn{2}{|c|}{ Process: Ensuring the required infrastructure and support teams to guarantee the quality of care. } \\
\hline Outcome & Indicators \\
\hline $\begin{array}{l}\text { Lighting, hygiene and furni- } \\
\text { ture of the patient and the } \\
\text { care unit with an infrastruc- } \\
\text { ture compatible with safe care. }\end{array}$ & $\begin{array}{l}\text { - \% of ideal patient units, available in the service (bed, mattress, bedding, beside table, } \\
\text { table, individual light, nurse call button, connection to oxygen, air and suction). } \\
\text { - \% of services with care facilities, isolation precautions, procedure or minor surgery } \\
\text { rooms, as appropriate; patient bathroom in each room. } \\
\text { - \% of services that comply with patient isolation standards. } \\
\text { \% of services with storage facilities for supplies, storage facilities for clothing according to } \\
\text { BTS. } \\
\text { - \% of services with a rest area and bathroom for the staff. } \\
\end{array}$ \\
\hline \multicolumn{2}{|c|}{ Process: Addressing human needs according to risk and dependence. } \\
\hline Outcome & Indicators \\
\hline $\begin{array}{l}\text { Standardized and personalized } \\
\text { care plan covering human } \\
\text { needs according to risk and } \\
\text { dependence. }\end{array}$ & $\begin{array}{l}\text { - } \quad \text { Nursing protocols of patient admission to and discharge from the unit. } \\
\text { - } \quad \text { Protocol of risk and dependence assessment. } \\
\text { - } \quad \% \text { of planits with patients distributed according to risk and dependence. } \\
\text { - } \quad \text { of of standardized plans according to risk, dependence and care needs per condition and } \\
\text { nursing process. } \\
\text { - } \quad \text { \% of uns-categorization program between the different units. } \\
\end{array}$ \\
\hline \multicolumn{2}{|c|}{ Process: Application of the nurse's judgment to the implemented activities resulting from medical diagnosis and treatment. } \\
\hline Outcome & Indicators \\
\hline $\begin{array}{l}\text { Nursing care plan incorporat- } \\
\text { ing the need resulting from } \\
\text { the medical diagnosis and } \\
\text { treatment. }\end{array}$ & $\begin{array}{l}\text { - } \quad \text { Manual of nursing procedures. } \\
\text { - } \quad \text { Institutional standard for medication administration. } \\
\text { - } \quad \text { Notocol addressing omissions, errors or therapeutic non-adherence. } \\
\text { - } \quad \text { No. of patients non-adherent to treatment (omissions, errors). } \\
\end{array}$ \\
\hline
\end{tabular}




\begin{tabular}{|c|c|}
\hline \multicolumn{2}{|c|}{ Process: Coordination with professionals and support units for medical diagnosis and treatment. } \\
\hline Outcome & Indicators \\
\hline $\begin{array}{l}\text { Communication channels and } \\
\text { logistics for the management } \\
\text { of supplementary support } \\
\text { for medical diagnosis and } \\
\text { treatment. }\end{array}$ & $\begin{array}{l}\text { - } \quad \text { Manual on the organization of the Care Management unit. } \\
\text { - } \quad \text { Nursing protocol, change-of-shift. } \\
\text { - } \quad \text { \% of compliance with critical procedures for diagnosis and treatment performed accord- } \\
\text { - } \quad \text { Seng to the protocol in force in each unit. } \\
\end{array}$ \\
\hline \multicolumn{2}{|c|}{ Process: Provision of clinical supplies } \\
\hline Outcome & Indicators \\
\hline $\begin{array}{l}\text { Sufficient quality supplies } \\
\text { for fulfilling the therapeutic } \\
\text { needs of the clinical unit. }\end{array}$ & $\begin{array}{l}\text { - Critical and basic supplies requested by clinical services/units correspond to the supplies } \\
\text { delivered to these care units. } \\
\text { - No. of adverse events resulting from the quality of critical and/or basic supplies. } \\
\text { - } \quad \text { No. of care interventions performed using supplies from other care units. } \\
\text { - Regulation of a control and registry system for input and output of supplies per unit and/ } \\
\text { or service. } \\
\text { - }\end{array}$ \\
\hline
\end{tabular}

Source: Data obtained in the study

In the process of collective designing this model, identifying indicators, and, subsequently, summary indicators, has been difficult. This would certainly allow for the development of an easier-to-implement model. The thoroughness that characterizes Nursing influences all the aspects of each outcome, preventing some indicators from being more significant than others. This dimension does not consider processes in which the patient and his/her family are directly involved.

\section{Table 3}

\section{Power and Relationship With Others in Nursing dimension}

The Power and Relationship with Others dimension is understood as the need to:

- Claim the role of Nursing within hospitals, its social position and as a way to achieve gender equity.

- Empower the client-patient-partner so that he/she becomes more capable of making informed and responsible decisions and develop a citizenship in health.

- Define the boundaries of Care Management, the professionals and the circumstances involved. This dimension is present in the following processes:

\begin{tabular}{|c|c|}
\hline \multicolumn{2}{|c|}{ Process: Emotional support provided by the nursing team to individuals and families. } \\
\hline Outcome & Indicators \\
\hline $\begin{array}{l}\text { Patients and families emotion- } \\
\text { ally comforted, expressing } \\
\text { trust in the health care team. }\end{array}$ & $\begin{array}{l}\text { - \% of plans that include emotional care for the patient and the family. } \\
\text { - } \quad \text { Nursing protocol that defines the information to be provided to the patient and family. } \\
\text { information to the patient and family. } \\
\text { - Nursing protocol to cope with grief, as well as psychosocial and emotional support to the } \\
\text { family. } \\
\text { No. of interventions based on the protocol for the emotional support of the family in } \\
\text { case of death. } \\
\text { \% of complains and compliments made by families or users regarding the service and the } \\
\text { intervention of nurses and other professionals. }\end{array}$ \\
\hline \multicolumn{2}{|c|}{ Process: Respect for the expression of interest to participate and consent before nursing interventions, patients and relatives. } \\
\hline Outcome & Indicators \\
\hline $\begin{array}{l}\text { Patient and families informed } \\
\text { of risks, benefits and conse- } \\
\text { quences of the interventions. }\end{array}$ & $\begin{array}{l}\text { - Information protocols for the expression of interest to participate. } \\
\text { - Informed consent protocols for nursing actions. } \\
\text { - \% of clinical interventions to patients after their informed consent. }\end{array}$ \\
\hline
\end{tabular}




\begin{tabular}{|c|c|}
\hline \multicolumn{2}{|c|}{ Process: Management of personal/group skills, competences and preferences in clinical units } \\
\hline Outcome & Indicators \\
\hline $\begin{array}{l}\text { Staff with cognitive and } \\
\text { emotional training meets the } \\
\text { current needs of clinical units, } \\
\text { users and their families. }\end{array}$ & $\begin{array}{l}\text { - Standardized instrument to assess the Nursing team. } \\
\text { - } \quad \text { of remarks of merit and demerit. } \\
\text { - } \quad \text { Reguluation of the performance of the nursing team members. } \\
\text { - } \quad \text { of staff members who meet the profile of clinical work skills identified in the skills profile. } \\
\text { - } \quad \text { of employees who participate in service orientation and induction activities. } \\
\text { - Protocols for the emotional support in stressful situations. }\end{array}$ \\
\hline \multicolumn{2}{|c|}{ Process: Ensuring the continuity of nursing care in the clinical unit, the healthcare network, and the family. } \\
\hline Outcome & Indicators \\
\hline $\begin{array}{l}\text { Patient with higher level of } \\
\text { self-care and follow-up on the } \\
\text { prescribed treatment and sup- } \\
\text { port in health check-ups. }\end{array}$ & $\begin{array}{l}\text { - } \quad \text { \% of patients who are readmitted due to preventable complications. } \\
\text { - } \quad \text { Nursing program for cooperation with the healthcare network. } \\
\text { - } \quad \% \text { of patients with follow-up after discharge. } \\
\text { - } \quad \% \text { of patients who comply with the scheduled health check-ups after hospitalization. }\end{array}$ \\
\hline \multicolumn{2}{|c|}{ Process: Negotiation and communication of Care Management achievements in the institution and in the community. } \\
\hline Outcome & Indicators \\
\hline $\begin{array}{l}\text { Active participation of nursing } \\
\text { professional(s) in decision- } \\
\text { making concerning care man- } \\
\text { agement in the institution and } \\
\text { clinical unit. }\end{array}$ & $\begin{array}{l}\text { - \% of nursing professionals who participate in technical meetings of the unit. } \\
\text { - \% of nursing professionals involved in technical and administrative meetings of the } \\
\text { institution. } \\
\text { - No. of nursing professionals involved in high-level committees in the institution or in the } \\
\text { health care network. } \\
\text { - Annual program of meetings with nursing professionals. }\end{array}$ \\
\hline
\end{tabular}

Source: Data obtained in the study

It's been difficult to sinthethize this process in a few indicators. An exhaustive reviewing process, and controlling habits have been conceptualised as part of a good nursing pactice imperative, as found in the results. This dimension is composed of processes directly related to the patient and his/her family and also to those who support this relationship at the strategic and logistic levels.

Table 4

\section{Nursing Training and Research dimension}

The Nursing Training and Research dimension refers to:

- The need to provide nurses with specific training that incorporates innovation in their practice and ensures nursing Care Management oriented toward the person, the patient, the family, the nursing staff and the multidisciplinary team.

- The lack of a scientific model to deal with complexity and shift from a biomedical positivist model to a biopsychosocial integrated model. This dimension is present in the following processes:

\begin{tabular}{|c|c|}
\hline \multicolumn{2}{|c|}{ Process: Professionalization of nursing care } \\
\hline Outcome & Indicators \\
\hline $\begin{array}{l}\text { Care is based on the nurse's } \\
\text { judgement and on a nursing } \\
\text { model, and it balances stan- } \\
\text { dardized care and personalized } \\
\text { care. }\end{array}$ & $\begin{array}{l}\text { - Nursing care model based on the strategic planning of Care Management that meets the } \\
\text { requirements of the service and/or unit. } \\
\text { - } \% \text { of standardized plans based on risk-dependence and needs. } \\
\text { - } \% \text { of personalized plans based on risk-dependence and needs. } \\
\text { - } \quad \text { \%o. of nursing professionals associated or affiliated to scientific societies. }\end{array}$ \\
\hline \multicolumn{2}{|c|}{ Process: Evaluation, continuous improvement and projection of the quality of care. } \\
\hline Outcome & Indicators \\
\hline $\begin{array}{l}\text { Continuous improvement } \\
\text { plans and strategic tools in the } \\
\text { clinical unit and institutions } \\
\text { developed by the nursing } \\
\text { professionals of the unit. }\end{array}$ & $\begin{array}{l}\text { - Strategic plan in the care management unit of the institution. } \\
\text { - Strategic plan in the service and/or clinical unit. } \\
\text { - } \quad \text { of of strategic plans developed and/or with the participation of nursing professionals. } \\
\text { - } \quad \text { monitoring of critical incidents, protocols). } \\
\text { - Regular public accounts on the quality of the provided nursing care. }\end{array}$ \\
\hline
\end{tabular}




\begin{tabular}{l|ll}
\hline Process: Production of local evidence. \\
\hline Outcome & Indicators \\
\hline & $\bullet \quad$ Number of Nursing research studies annually conducted in the service. \\
Local studies that enhance the & $-\quad$ Number of Nursing research studies disseminated in journals and conferences. \\
nurses' evidence-based prac- & $-\quad$ Number of updated and revised protocols with the participation of Nursing professionals. \\
tice. & $-\quad$ Number of case studies conducted in the unit. \\
& $-\quad$ Nursing research committee operating in the hospital center. \\
\hline
\end{tabular}

Process: Training of professional and technical Nursing skills.

\begin{tabular}{l|l}
\hline Outcome & Indicators \\
\hline $\begin{array}{l}\text { Quality and ethical professional } \\
\text { learning opportunities based }\end{array}$ & $\bullet \quad \%$ of Nursing professionals who teach within the unit and/or service. \\
on clinical experience. & $\bullet \quad \%$ of students who recognize comprehensive and quality learning experiences. \\
\hline
\end{tabular}

Source: Data obtained in the study

This dimension can certainly allow for the reduction of its indicators when prioritizing the most important ones. This dimension not only considers processes directly related to the patient and his/her family, but also those who support this relationship at the strategic and logistic level.

\section{Discussion}

The identification of different dimensions to describe the concept of Care Management clarifies the different perspectives on the concept. The professional domain is guided by the cost-effectiveness of nursing actions, the union domain by the relationships of power and the boundaries of Care Management, and the academic domain by training and research. They present a supplementary, inclusive and synergetic whole. For example, the power dimension addresses the social and cultural background of the level and type of empowerment of nursing professionals, the conditions on which they assume the legal and social responsibility in managing the care provided to an individual and his/her family in a healthcare center. This is consistent with achieving further social valuation for the profession, while expanding other aspects related to professional career management and in-depth training (Federico-Ferreira \& Ribeiro da Silva, 2012).

Moreover, translating these dimensions into care management-related processes shows that processes are apprehended through procedures or techniques or through the nursing care process. Therefore, the answers are less assertive and few experts provide plausible proposals. This reflective level is consistent with the use of the concept in the health system in Chile and with the absence of this aspect in various reflections that prefer to address the conceptual and structural aspects, without an explicit mention to the clinical processes associated with care management that mediate them (Milos, Borquez, \& Larrain, 2010). A relevant bias in this research is that the decision on the essential clinical processes of Care Management was influenced by the analysis of the research team as a result of the lack of homogeneity in the experts' answers related to the notion of clinical process. However, the experts validated the proposal. Interestingly, the nurses found the processes and products proposed by the research team to be meaningful, which at least allows for its local validation.

A clinical process, i.e. a process that is developed in a healthcare institution, is user-focused, and searches for comprehensive results that involve the action of a team and the concurrence of other processes within a client-provider logic. The perspective of processes is associated with Quality Management because its operationalization helps to make the necessary changes that allow for the development and implementation of new methodologies toward patient and staff satisfaction (Antunes \& Trevisan, 2000). Consequently, it is necessary to improve the knowledge on the concept of clinical process and gain the ability to view it as a structuring aspect of the organization of clinical services, technical skills and required supplies, as well as the liaisons that must be established with other clinical units, and encourage changes for the organizational improvement of hospital management and optimization of the use of allocated resources (Milos, Borquez, \& Larrain, 2010; Torres, 2014).

Therefore, the visibility of clinical processes and the design of assessment tools with a high level of validity and reliability are essential to objectively identify 
the technological gaps, the disrupted relationships, and the obstacles that hinder the achievement of the best possible quality (Subsecretaria de Redes Asistenciales, 2007). Thus, the information provided by an assessment instrument for the quality of care management may contribute to address training, allocate the material resources needed to close the gaps, and identify the contextual aspects that impede quality. As well, quality certification in care management puts into evidence the Nursing contribution to the organization of clinical services based on nurse care needs, more than clinical organization based on medical diagnosis, which can lead to lack of flexibility and lack of vacant beds, not contributing to efficiency at use of beds for inpatients. It also provides the necessary framework to base practices in evidence and to facilitate the transition from the Cartesian positivism toward a more inclusive and systemic paradigm, concepts that are increasingly present among Nursing theorists (McFarland \& Wehbe-Ala, 2006; Lachman, 2012).

From a different perspective, an assessment tool attached to a model of quality also provides the possibility of cross-referencing results, if the instrument is applied on several occasions to the same people or in similar situations. If the processes are developed based on quality and following an explicit model, the attitudinal skills gain added value, given that, from the perspective of the processes, it is evident that all people involved are relevant to quality certification.

The methodology used in this research study provides the necessary bridge between training and practice, between research findings and their usability, allowing for a swift approach toward quality, strengthening and enriching the research process. It also provides space for reflection on everyday nursing issues that require attention and in-depth knowledge, such as the patient and family education, the importance of emotional support, and the continuity of care within the healthcare network, among others. For example, a focus group suggested the inclusion of the mandatory development of a Manual on Care Management Organization, which would contribute to defining the organization of the unit, delimitating the nursing work, and creating position profiles, keeping consistency with what is proposed in the present quality certification model.

Quality can be a health asset very difficult to measure due to its subjectivity, the measurement of abstract concepts, and the influence of various interests. Therefore, assessing quality requires a quantitative operationalization that allows cross-referencing results and establishing longitudinal and contextual comparisons. It also needs patterns to be determined in order to allow for the identification of failures or achievements (Jimenez, 2004). The clarification of the expected outcomes and indicators determines how this quality model can provide a way to define a good, medium or low quality care management.

\section{Conclusion}

The design of a model that certifies the quality of care management in inpatient care implies the objective identification and operationalization of concepts and practices. Assuming definitions regarding quality requires decisions from a particular epistemic, financial and opportunity perspective. Certainly, a model is a reference, not a set standard and, therefore, it requires adaptations and adaptability to be implemented in different contexts.

The operationalization of care management, as a holistic and comprehensive concept, has the same requirements because it covers all the domains of the professional exercise of inpatient care. However, Care Management does not seem to belong to the Nursing field, despite its practical component. Therefore, it is necessary to distinguish it from its philosophy and its disciplinary foundations.

As research task, the objective identification and operationalization of the design of a quality model for care management in inpatient care has showed a clear progression toward the better and more accurate processes, outcomes and indicators for every dimension of Care Management in each consecutive consultation and focus group. Essentially, the experts propose the model and the focus groups assess it in order to bring it closer to their practice, based on the empirical evidence of their work and their ethical values.

Although this quality certification in care management is based on processes focused on inpatient care, the indexes, magnitudes, preponderances and prioritizations of the indicators and processes remain undefined. 


\section{References}

Amezcua, M. (2003). La entrevista en grupo: Características, tipos y utilidades en investigación cualitativa. Enfermeria Clínica, 13(2), 112-117. doi:10.1016/S1130-8621(03)73791-7

Amezcua, M., \& Galvez, A. (2002). Los modos de análisis en investigación cualitativa en salud: Una perspectiva crítica y reflexiones en voz alta. Revista Española de Salud Pública, 76(5), 423-436. Retrieved from http://scielo.isciii.es/pdf/ resp/v76n5/colabora4.pdf

Antunes, A., \& Trevisan, M. (2000). Gerenciamiento da qualidade: Utilizacao no servico de enfermagen. Revista LatinoAmericana da Emfermagen, 8(1), 35-44. Retrieved from http://www.scielo.br/pdf/rlae/v8n1/12432.pdf

Astigarraga, E. (s.d.). El método delphi. San Sebastian, Espanã: Universidad de Duesto. Retrieved from http://www. unalmed.edu.co/ poboyca/documentos/documentos1/ documentos-Juan\%20Diego/Plnaifi_Cuencas_Pregrado/ Sept_29/Metodo_delphi.pdf

Ayala, R. (2014). Niveles de planificación en la gestión del cuidado. In Ricardo M. C. \& V. Ayala, Gestión del cuidado en enfermería (pp. 139-152). Santiago de Chile, Chile: Meditarráneo.

Bertoldi, S., Fiorito, M., \& Álvarez, M. (2006). Grupo focal y desarrollo local: Aportes para una articulación teóricometodológica. Ciencia, Docencia y Tecnología, 17(33), 111-131. Retrieved from http://www.redalyc.org/articulo. oa?id $=14503304$

Bravo, M., \& Arrieta, J. (2005). El método Delphi. Su implementación en una estrategia didáctica para la enseñanza de las demostraciones geométricas. Revista Iberoamericana, 35(3). Retrieved from http://rieoei.org/ deloslectores/804Bravo.PDF

Castillo, E., \& Vásquez, M. (2003). El rigor metodológico en la investigación cualitativa. Colombia Médica, 34(3), 164167. Retrieved from http://www.redalyc.org/articulo. oa?id $=28334309$
Federico-Ferreira, M., \& Ribeiro da Silva, C. (2012). Reformas da gestao na saude: Desafios que se colocan oas enfermeiros. Revista de Enfermagen Referencia, 3(8), 85-93. doi: 10.12707/RIII1238

Gobierno de Chile. (1968). Código Sanitario Chileno. Santiago de Chile, Chile: Ministerio de Salud.

Gobierno de Chile. (2004). Ley de Autoridad Santaria, Decreto fuerza de ley 725. Santiago de Chile: Ministerio de Salud.

Jimenez, R. (2004). Indicadores de calidad y eficiencia de los servicios hospitalarios. Revista Cubana de Salud Pública, 30(1), 17-36. Retrieved from http://www.bvs.sld.cu/revistas/ spu/vol30_1_04/sp04104.htm

Lachman, V. (2012). Applying the ethics of care to your nursing practice. Medsurg Nursing, 21(2), 112-116. Retrieved from http://www.nursingworld.org/MainMenuCategories/ EthicsStandards/Resources/Applying-the-Ethics-of-Care-toYour-Nursing-Practice.pdf

McFarland, M., \& Wehbe-Ala, H. (2006). Leininger's culture, care diversity and unversality: A wordwide theory. Burlington, USA: Jones\&Barnes Learning.

Milos, P., Borquez, B., \& Larrain, A. (2010). La gestión del cuidado en la legislación chilena: Interpretación y alcance. Ciencia y Enfermería, 16(1), 17-29. doi:10.4067/S071795532010000100003

Subsecretaria de Redes Asistenciales. (2007). Norma general admistrativa $\mathrm{N}^{\circ}$ 19. Gestión del Cuidado de Enfermeria para la Atención Cerrada. Santiago de Chile: Ministerio de Salud.

Torres, E., M. (2008). Metodologia para definir funciones profesionales. Revista Cubana de Enfermeria, 34(4), 17-29. Retrieved from http://scielo.sld.cu/scielo.php?script $=$ sci arttext\&pid $=$ S0864-34662008000400017

Torres, M. (2014). Gestión clínica y del cuidado. En R. Ayala, M. Torres, \& M. Calvo, Gestión del Cuidado en Enfermería. (pp. 105-138). Santiago de Chile, Chile: Ed. Mediterráneo

Yáñez, R., \& Cuadra, R. (2008). La técnica Delphi y la investigación en los servicios de salud. Ciencia y Enfermería, 14(1), 9-15. 